\begin{abstract}
S
Olivier Rozenberg

France's Search for a New European Narrative

For a long time, French politicians have viewed France's participation in European integration as a justification for the preservation of its power through the framework of Europe. However, France's position in the European Union seems to become less and less linked to the idea of "Europe puissance". In spite of the slow erosion of this idea, and due to cultural as well as institutional reasons, French policy makers have not been able to create an alternative national narrative which would justify European integration. In addition to the anti-European stance of the winning faction "Front National", the biggest winner of the 2014 European elections, there has also been a diffusion of European skepticism throughout the governing parties in France.
\end{abstract}

\title{
András Inotai
}

\section{One Decade of Hungary's Membership in the European Union: A Critical Appraisal of Benefits and (Self-made) Costs}

The paper offers a critical survey of Hungary's EU membership through analysis of key expected benefits, including trade, free circulation of persons and capital, impact of EU transfers and full-fledged participation in the decision-making process of the integration. Free trade has generated two rapid increase of trade with new EU members and a substantial Hungarian trade surplus. Compared to other new members, the Hungarian labour force remained rather immobile at the start of membership, but revealed enhanced mobility after the formation of a new government in 2010. Since 2007 Hungary has been one of the major beneficiaries of EU funds, unfortunately a large part of that money could have been managed much more efficiently. The current government's increasingly critical view of the European integration process, implementation of "unorthodox" economic (and social) policies has made Hungary, as of today, the only member country with a government-level anti-EU attitude.

\section{Stefan Gänzle and Kristine Kern}

The EU Strategy for the Baltic Sea Region: Evolution and Contemporary Perspectives of a New Approach in EU Regional Policy

With the adoption of the macro-regional strategies for the Baltic Sea, Danube and the Adriatic-Ionian regions in 2009, 2011 and 2014 respectively, the European Union has introduced a new concept in EU regional policy. Building on the EUROPE 2020 program as well as existing forms of regional cooperation, these strategies aim at the establishment of a new integrated framework for transnational collaboration involving both EU member states and partner countries from the same geographical, cultural and functional space. This article analyses the extent to which the EU Strategy for the Baltic Sea has hitherto lived up to its objectives and what kind of impact it has triggered vis-à-vis regional organizations with a view to improving cooperation between actors and across polices in the Baltic Sea region. 
Timm Beichelt

Incompatible Positions and Antagonistic Challenges - the Eastern Partnership Policy of the $\mathbf{E} \mathbf{U}$

The European Neighbourhood Policy (ENP) and the Eastern Partnership (EP) are controversial issues among political actors and the Public. This article identifies three contentious issues: sovereign statehood, international alliance capacities and the EU accession perspectives of the EP countries. Since no hegemonic opinions regarding all three issues could establish itself on the international level, the character of the EU association process is antagonistic. As long as the actors of the EU do not accept this fact, the strategy towards the eastern European neighbours cannot be consistent and is thus doomed to failure.

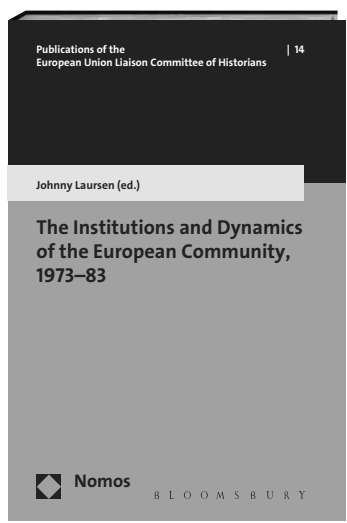

The Institutions and Dynamics of the European Community, 1973-83

Herausgegeben von Johnny Laursen

2014, 312 S., geb., 82,-€

ISBN 978-3-8329-6963-9

(Veröffentlichungen der Historiker-Verbindungsgruppe bei der Kommission der EG, Bd. 14)

www.nomos-shop.de/14061

Gestützt auf neue, aus Archivmaterial und Interviews gewonnene Erkenntnisse bietet die Publikation einen neuen Blick auf die Geschichte dieser speziellen Epoche der europäischen Integration. Die Autoren interpretieren diesen Zeitraum neu, als Periode der Krise und Stagnation, und diskutieren deren Bedeutung für den Integrationsprozess.

In englischer Sprache.

Bestellen Sie jetzt telefonisch unter 07221/2104-37 Portofreie Buch-Bestellungen unter www.nomos-shop.de Alle Preise inkl. Mehrwertsteuer

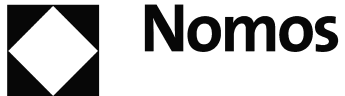

